\title{
LATE REPUBLICAN (R)EVOLUTIONS IN ROMAN LAW
}

\section{Philip THOMAS*}

\begin{abstract}
In this article it is argued that the re-organisation of the Roman military by Marius prepared the way for the following civil wars and dictatorships rather than the inherent failures of the republican constitution. This paper sketches the socio-political context of Cicero's life and holds that this last republican left an important theoretical body of legal work besides his court work. Cicero's moral philosophy is reflected in his belief in natural law and his staunch partisanship for the power of good faith in Roman law.
\end{abstract} law.

Keywords: Roman law, Roman republic, negotia bonœ fidei, Cicero, natural

* Professor emeritus of Roman law, University of Pretoria, philip.thomas231@gmail.com. 


\section{Table of Contents}

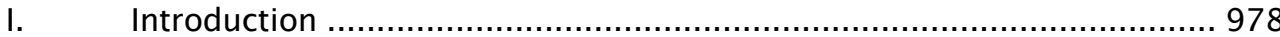

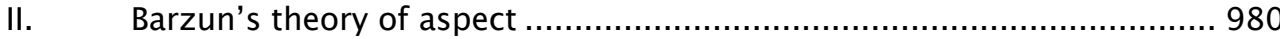

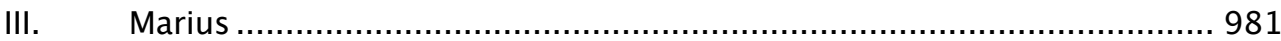

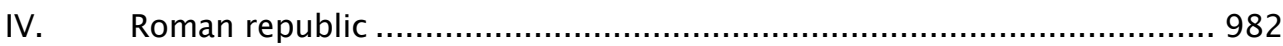

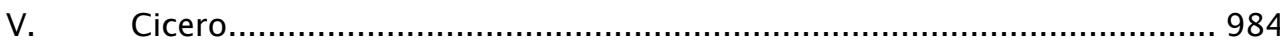

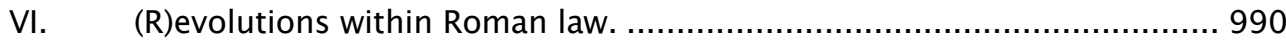

VII. Origin of negotia bonae fidei and the timeline of their enforceability ..... 993

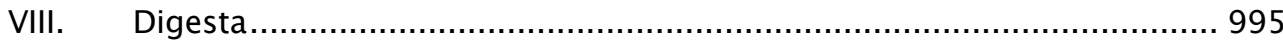

IX. Conclusion ............................................................................ 1000

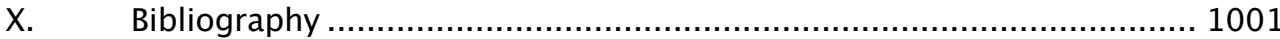

\section{Introduction}

The last century of the Roman republic may well be described as a permanent revolution. The Social war, various civil wars, the slave rebellion and the dictatorships and triumvirates brought the republican constitution stuttering to its demise. ${ }^{1}$ The insightful interpretation of habent sua fata libelli by Prof Hanga who wrote in 1979 “The aphorism habent sua fata libelli

\footnotetext{
${ }^{1}$ 91-88 BC: Social war between Rome and many of its Italian allies;88-87 BC: Sulla's first civil war (88-87 BC), between Lucius Cornelius Sulla and Gaius Marius;82-81 BC: second civil war between Sulla and Marius;82-72 BC: Sertorian war between Rome and the Provinces of Hispania under the leadership of Quintus Sertorius, a supporter of Gaius Marius;77 BC: Lepidus' rebellion against the Sullan regime;73-71 BC: Third Servile war in Italy; Spartacus revolt suppressed;49-45 BC: Caesar's civil war between Julius Caesar and the optimates initially led by Pompey the Great (Gnaeus Pompeius Magnus);44-43 BC: Post-Caesarian civil war between the senate's army (led first by Cicero and then by Octavian) and the army of Antony, Lepidus, and their colleagues;44-42 BC: Liberators' civil war between the second Triumvirate and the liberators (Brutus and Cassius, Caesar's assassins);44-36 BC: Sicilian revolt between the second Triumvirate (particularly Octavian and Agrippa) and Sextus Pompey, the son of Pompey;32-30 BC: Final war of the Roman republic between Octavian and his friend and general Agrippa against Antony and Cleopatra.
} 
of the Latin teacher Terentianus Maurus, contains an idea which is also easily applicable to legislation, because in fact, each legislation is linked to the society from which it originates and on which it depends. If social changes require new regulations, the old laws are replaced by new ones. In other words "habent sua fata leges."2 This idea may without doubt be extended from legislation to law. Today it is increasingly realised that the late republican era made an undervalued contribution to the development of Roman law. Obvious explanations for this oversight are the dearth of sources from this period in the Digest as well as the tenacity of the Mommsenian ${ }^{3}$ myth that the most important representative of the Republican elite was Julius Caesar rather than Marcus Tullius Cicero. Moreover, Mommsen's animosity 4 drove him as far as calling Cicero "an unworthy vessel" as well as denigrating his legal knowledge and skills. Especially the categorical statement that Cicero had never been a "jurist" has proven hard to eradicate. .5 This last prejudice is to be deplored since it has led to neglect of the most prolific source on late republican law by subsequent guilds of romanists and legal historians and to widespread ignorance of his contribution to the development of Roman law.

This paper intends to sketch the socio-political context in which Cicero lived and worked and propose a hypothesis relative to the characteristic of his legal authorship. In order to do so, three different major transformations

2 V. Hanga, ”Römisches Recht und aktuelles Recht," KLIO, 1979 (61, 1-2), 131-143.

3 For Theodor Mommsen cf.

https://www.nobelprize.org/prizes/literature/1902/mommsen/biographical/;

https://www.britannica.com/biography/Theodor-Mommsen;

https://www.livius.org/articles/person/mommsen/

4 M.S. Slaughter, "Cicero and his Critics", The Classical Journal, 1921 (17, 3), 210-131. For M. S. Slaughter $c f$. https://www.wisconsinhistory.org/Records/Article/CS13052.

5 F. Wieacker, Cicero als Advokat: Vortrag gehalten vor der Berliner Juristischen Gesellschaft am 29. April 1964, Berlin 1965; see also J. Powell and J. Paterson, Cicero The Advocate, Oxford 2003; J. Harries, Cicero and the Jurists From citizen's law to the lawful state, London 2006. 
during the late Roman republic will be viewed from the perspective of the theory of aspect of Barzun. This allows for alternative interpretations concerning first the demise of the Roman republic, secondly the legal expertise of Cicero and thirdly, the development of good faith in the Roman law of contracts.

\section{Barzun's theory of aspect}

The Franco-American historian Jacques Barzun founded his magisterial work From Dawn to Decadence ${ }^{6}$ on his theory of aspect. Although not stated explicitly his work clearly negates holism ${ }^{7}$ as it is based on the proposition that no event, object or person can ever be viewed in her totality. He uses the metaphor of a mountain which presents multifarious aspects and is impossible for the observer to view in its totality. Instead one or a few aspects are absorbed and considered to be the totality or the essence. ${ }^{8}$ Barzun held that this assumption explains the amazing diversity in interpretation by historians vis-à-vis historical persons and events and results in the depiction of different pasts. ${ }^{9}$ He acknowledges partiality as an unalterable fact of life,

\footnotetext{
${ }^{6}$ Jacques Barzun, (1907 - 2012), From Dawn to Decadence 500 Years of Western Cultural Life 1500 to the Present, New York City 2000.

7 Jan Smuts, Holism and evolution, London 1926; J. C. Poynton, "Smuts holism and evolution sixty years on," Transactions of the Royal Society of South Africa, 1987 (46 3), 181-189.

${ }^{8}$ At 46-47, 174, 246-7, 250, 253, 430-1, 435-437, 568-574, 652-656, 759-763, 768-9.

9 Philip Thomas, “The standpoint determines the view: Jacques Barzun's theory of aspect”, in Paul J. du Plessis, New Frontiers Law and society in the Roman world, Edinburgh 2013, 227244.
} 
which must be accepted, thus jettonising the so-called scientific objectivity ${ }^{10}$ of positivism. ${ }^{11}$

In a Festschrift dedicated to professor Hanga, Marcus Tullius Cicero and the late Roman republic are obvious candidates for application of the theory of aspect. This should include a dusting off of some half- forgotten role players during this period and have another take on Cicero's contribution to Roman law. It is proposed that the catalyst of the demise of the Roman republic was Gaius Marius, who was an antipode to Cicero, who spent his lifetime defending the republic and gave his life to this end.

\section{Marius}

The role of this un-educated son of a middle class, newly Roman, provincial family in the de-construction of the Roman republic has been underplayed. A common man with more brawn than brain, who was driven by ambition and showing a natural talent for matters military, Marius ${ }^{12}$ made a spectacular career in the Roman army.

10 H.R. Hoetink, "Het waarde-oordeel in de sociale wetenschappen," in Rechtsgeleerder opstellen, Alphen aan den Rijn 1982, 274-296; Jan Romein, "Zekerheid en onzekerheid in de geschiedwetenschap Het problem der historische objectiviteit," in Historische lijnen en patronen, Amsterdam 1976, 90- 118; John Burrow, A history of histories, London 2009; Reiss, Julian and Jan Sprenger, "Scientific Objectivity", The Stanford Encyclopedia of Philosophy (Winter 2017 Edition), Edward N. Zalta (ed.), at https://plato.stanford.edu/archives/win2017/entries/scientific-obectivity.

${ }^{11}$ Masahito Hirai, "Objectivity in the Beginnings of the Positivism: Dispute between Auguste Comte and Émile Littré,” Archive for Philosophy and the History of Science 2026 (18), 25- 39. 12 This is not an in-depth purely historical study and relies on general encyclopedic knowledge and Plutarchus' lives as primary source. $C f$. Plutarch's Lives. Dryden edition revised \& with an introduction by Arthur Hugh Clough in vol. 2, London 1932, 75-115; https://www.britannica.com/biography/Gaius-Marius. 
Through important protectors and playing the populist card Marius became the homo novus of Roman politics, but showed no respect for the Roman constitution and the rule of law.

However, he introduced important innovations in the Roman military, the main being the reduction of the property requirement, thus opening the future of the professional military. The war against the Cimbri, Teutones and Ambrones led to his serial consulships and ultimate victory. Marius was popular with his soldiers in spite of being hard on them, because he shared their life. He relied on the loyalty of his troops to achieve political power, and thus set the matrix for the downfall of the Roman republic. Sulla, Pompeius, the triumviri, Caesar, Marcus Antonius and Octavianus are metaphorically speaking his illegitimate offspring as they consciously cultivated their troops in order to rely on them in the advancement of their political careers.

A short remark regarding the republic, which is generally considered as undemocratic, outdated and unsuited to rule an empire, but considered worthwile dying for by Cicero, may be appropriate.

\section{Roman republic}

The Roman republic ${ }^{13}$ was not founded on a written constitution. Instead old traditions going back to the times of Romulus and Numa, or dating from the period following the overthrow of the monarchy as well as the leges Liciniae Sextiae ${ }^{14}$ were supplemented and adapted by occasional legislation. The eternal, simmering conflict between rich and poor in Rome

\footnotetext{
13 510-27 B.C. H.F. Jolowicz, Historical Introduction to the study of Roman law, Cambridge 1952, 1-6. 7-55.

14 Jolowicz, 13-16; Burrows, Part II Rome, 67- 175.
} 
was reflected in the "balanced" variety of legislative bodies ${ }^{15}$ and magisterial offices, ${ }^{16}$ which succeeded to an extent to maintain social harmony. The demand for equal rights by the other inhabitants of Italy resulted in the gradual granting of Roman citizenship. ${ }^{17}$ Moreover, the Roman republic succeeded in establishing an empire around the Mediterranean basin by conquest and more to the point, successfully maintaining and administering the same. The parallel development of Roman private law was made possible by the introduction of the praetor peregrinus ${ }^{18}$ and the procedure per formulam. ${ }^{19}$

The late republic was a crucial period in development of the Roman imperium. Border wars with Jugurtha and Mithridates alternated with the direct threat to Rome by Cimbri, Teutones and Ambrones. Simmering tensions within Italy erupted in the Social War and the Spartacus revolt. Within Rome herself the eternal gap between rich and poor reached a dangerous stalemate with "panem et circenses."20

However, the republican "system" adapted successfully to the new imperial role and Roman magistrates established pax romana and rule of law around the Mediterranean from Sicily, Spain, Greece into the Middle East and Northern Africa. The military successes and economic expansion brought

15 Id. 16-43.

16 Id. $43-55$.

17 Id. 56-66.

${ }^{18}$ Id. 47, 99; Francis de Zulueta, The Institutes of Gaius, Part II Commentary, Oxford 1953, 17, 147, $253 \mathrm{f}$.

19 De Zulueta, $251 \mathrm{ff}$.

20 Juvenal, Satura X; http://www.ancient-literature.com/rome juvenal satire x.html. Juvenal ridicules how the Roman citizens had exchanged freedom and political influence for the dole and free entertainment by gladiatorial games in the circus. $C f$. https://fee.org/articles/poor-relief-in-ancient-rome/. 
hitherto unknown wealth into Italy, with the result that Roman law transformed and the fight for power and wealth intensified.

\section{Cicero}

The role model Marius stands in sharp contrasts to another provincial from the same region, namely Cicero. ${ }^{21}$ The latter's classical education and humanity led him on a political career aimed at avoiding civil war and bloodshed. Fighting his lifelong battle for the preservation of the republican constitution and the rule of law Cicero's life ended with his murder, in another contrast to the murderous Marius who died from old age and natural causes.

The ups and downs of Cicero's curriculum vitae are common knowledge. His many talents and wide range of interests make it impossible to pigeonhole him with the result that his mastery of the Latin language, his successes in the courts and several of his surviving publications caused him to be categorised as an orator.

In consequence, Mommsen's animosity towards Cicero combined with the $19^{\text {th }}$ century domination of German "Rechtswissenschaft" in the discipline of Roman law, cast a shadow over the $20^{\text {th }}$ century study of Roman law with the result that Cicero's work was considered a non-legal source.

If it is possible to state that in the present day a communis opinio can be found among romanists, the opinion of Schulz depicted in the History of

\footnotetext{
21 Plutarch's Lives, “The life of Cicero” at http://classics.mit.edu/Plutarch/cicero.html; A. Trollope, The life of Cicero at https://www.gutenberg.org/files/28676/28676-h/28676-h.htm; Marcus Tullius Cicero at https://www.britannica.com/biography/Cicero.
} 
Roman legal science ${ }^{22}$ still holds sway. ${ }^{23}$ Schulz believed that during the late republic the leading jurists still belonged to the upperclass, ${ }^{24}$ albeit that some homines novi succeed in law and politics, ${ }^{25}$ and even began to charge for their services. ${ }^{26}$ Advocates are a group apart and some have a little legal knowledge. ${ }^{27}$ Schulz mentions Cicero by name and states categorically his belief that the latter had acquired some elementary legal knowledge, ${ }^{28}$ but no understanding of legal science. ${ }^{29}$ These Roman jurists were opposed to Greek pedagogics, ${ }^{30}$ did not teach, did not appear in court, were not interested in natural law, legal history, methodology, comparative law, philosophical speculations about justice nor a sociological approach. ${ }^{31}$ Nevertheless, their

22 F. Schulz, History of Roman legal science, Oxford 1946; Geschichte der römischenRechtswissenschaft, Weimar 1961.

${ }^{23}$ At 97, 98, 111-113. For a deconstruction of this myth see K. Tuori, Ancient Roman lawyers and modern legal ideals Studies on the impacts of contemporary concerns in the interpretation of ancient Roman legal history, Frankfurt am Main 2007, ch. 2 The birth of legal science 21-69.

${ }^{24}$ At 7 of. Honoratioren-Jurisprudenz. $C f$. also $47 f$.

25At $48 \mathrm{f}$.

${ }^{26}$ At 50 . At 58 he mentions that this group gave routine responsa, while the great jurists only advised their friends, important people or in difficult cases.

${ }^{27}$ At 5 off.

${ }^{28}$ Cicero studied law under Quintus Mucius Scaevola Augur.

29 At 52: eine völlige Fremdheit und Verständnislosigkeit gegenüber der höheren Rechtswissenschaft. This distinction is crucial for Schulz's argument in terms of which the leading jurists applied the dialectic method to the law and thus built a legal science based on system; These jurists remained impartial and were only interested in the truth, while the advocates used all means to win their case. Schulz praises the Roman jurists for banning the weed of rhetoric from their ranks, echoing the Senatus Consultum from 161 B C expelling Greek rhetors and philosophers from Rome, $65 \mathrm{ff}, 82 \mathrm{ff}, 100 \mathrm{ff}$.

${ }^{30}$ At 68.

${ }^{31}$ At $69,84 \mathrm{ff}$. 
responsa were authoritarian and authoritative. $3^{2}$ Rhetoric and topoi were used in court, but had nothing to do with Roman law or legal science..$^{33}$

This is not the place to enter into a discussion on the history of $20^{\text {th }}$ century Roman law, but it suffices to state that if Cicero had been considered a Roman jurist the work of Stroux, ${ }^{34} \mathrm{Kuhn}^{35}$ and Viehweg ${ }^{36}$ would have been appreciated differently by romanists, which might have changed the fate of Roman law. It is ironic that in the USA, a country within the common law jurisdictions, the aspect of Cicero as a jurist, has been recognised and

\footnotetext{
${ }^{32}$ At $72 f$.

33 At 86: Mit der griechischen Rhetorik aber haben sie (die Gerichtsredner) auch gewisse то́ло der Griechischen Rechtsphilosophie übernommen: ius naturae und ius civile, ius gentium und ius civile, ius scriptum und ius non scriptum, lex und mos als species des ius, ius und aequitas. Das alles ist griechischer Import, von dem die römischen Gerichtsredner zwar praktischen Gebrauch machen, der aber mit römischem Recht und römischer Rechtswissenschaft nichts zu tun hat. At 93: Aus alledem ergibt sich: Die römischen iurisconsulti konnten hier von der Rhetorik schlechthin gar nichts lernen.
}

34 J. Stroux. "Summum Ius Summa Iniuria. Ein Kapitel aus der Geschichte der interpretatio iuris" in Festschrift Paul Speiser-Sarasin (1926); reprint in J. Stroux, Römische Rechtswissenschaft und Rhetorik, Potsdam 1949, 9-66.

In 1926 Johannes Stroux, professor of classical philology at the University of Munich proposed his theory that rhetoric became the methodology of Roman law. Rhetoric replaced the old formalistic Roman law and provided the theory of interpretation of statutes with viewpoints and arguments, topoi or topica, and a dialectic process of argument and counterargument. P.J.Thomas, "Ars aequi et boni, legal argumentation and the correct legal solution", ZSS RA 2014 (131), 43f.; A. Triggiano, “«Conlega et familiaris meus»: note minime su Cicerone e Aquilio Gallo”, Index, 2010 (18), 394ff n. 109.

35 Thomas S. Kuhn, (1922-1996), American historian and philosopher of science. The Structure of Scientific Revolutions, London 1962, popularised the concept 'paradigm' and the idea that different paradigms competed for hegemony.

36 Th. Viehweg, Topik und Jurisprudenz. Ein Beitrag zur rechtswissenschaflichen Grundlagenforschung, München 1953, provided new impetus to the topoi theory. Viehweg distinguished between topical, problem-orientated argumentation as opposed to axiomatic, systematic-deductive legal reasoning. Legal historians considered Viehwerg's work legal theory. 
championed. ${ }^{37}$ Thus, Martha Nussbaum ${ }^{38}$ considers De Officiis "perhaps the most influential book in the Western tradition of political philosophy" as Cicero elaborates his theory of justice from which thinkers like Aquinas, Suarez, Gentili, Grotius, Wolff, Pufendorf, Kant and Adam Smith derived their theories of international law and justice. 39

Nussbaum is not alone in her re-evaluation of Cicero. $4^{40}$ Tobias Reinhardt ${ }^{41}$ states "Cicero applied for the first-time theoretical reflection on causation to legal problems. By adopting the Stoic distinction between sufficient and necessary causes, by naming negligence and action with intent as causally relevant categories which cut across the previous distinction, and

37 For example M.L. Colish, The Stoic Tradition from Antiquity to the Early Middle Ages, Leiden 1985, 65-152.

$3^{8}$ https://www.law.uchicago.edu/faculty/nussbaum.

39 M.C. Nussbaum, "Duties of Justice, Duties of Material Aid: Cicero's Problematic Legacy”, The Journal of Political Philosophy, $2000(8,2)$, 176-206.

40 See also E. W. Clayton (Professor in the Department of Political Science and Public Administration of Central Michigan University) in his essay Cicero (106-43 BC): "While Cicero is currently not considered an exceptional thinker, largely on the (incorrect) grounds that his philosophy is derivative and unoriginal, in previous centuries he was considered one of the great philosophers of the ancient era, and he was widely read well into the 19th century. Probably the most notable example of his influence is St. Augustine's claim that it was Cicero's Hortensius (an exhortation to philosophy, the text of which is unfortunately lost) that turned him away from his sinful life and towards philosophy and ultimately to God. Augustine later adopted Cicero's definition of a commonwealth and used it in his argument that Christianity was not responsible for the destruction of Rome by the barbarians." IEP (Internet Encyclopedia of Philosophy) http://www.iep.utm.edu/cicero/ (consulted on 28/6/2020); Also W. Nicgorski's work (www.pls.nd.edu/faculty-and-staff/walter-nicgorski) as well as D.H. van Zyl, Justice and Equity in Cicero, a critical evaluation in contextual perspective, Pretoria, 1991. It is impossible to mention and fruitless to summarise the secondary literature on Cicero's theory of justice and reference to the website Natural Law, Natural Rights and the American Constitution (http://www.nlnrac.org) and the Internet Encyclopedia of Philosophy must suffice.

${ }^{41}$ T. Reinhardt, Marcus Tullius Cicero Topica, Oxford, 2003. For Reinhardt's admirable work cf. Philip Thomas, "A Barzunesque view of Cicero: from giant to dwarf and back" in Paul J. du Plessis (ed.), Cicero's Law. Rethinking Roman Law of the late Republic, Edinburgh 2016, $18 \mathrm{ff}$. 
by many other points of detail he has created the terms in which discussion about causality in the law is conducted until the present day" ... and " $(t)$ here was no such thing as theoretical reflection on causation among Roman jurists until Labeo." 42

Finally, the thoughtful introduction to Cicero's Law. Rethinking Roman Law in the Late Republic43 by Paul du Plessis reflects the current position vis-à-vis Cicero within romanist studies.

Another dimension of Cicero's many aspects is his belief in natural law. Without entering the debate on this absorbing topic, but by providing a simplified summary of Cicero's main thoughts on nature, reason, conscience and natural law his work as jurist may be placed in perspective.

It is trite that Cicero was not an empty vessel translating Greek philosophy, but an original thinker who synthesised Greek philosophy and Roman pragmatism and tradition. 44 This led to his beliefs on nature and natural law. The essence of his beliefs is that nature endowed man with reason, but also a conscience. 45 This combination made it possible to discover the principles and rules of a universal and eternal system, namely natural law, ${ }^{46}$ which is equivalent to moral law and sets a higher standard than the

42 Reinhardt, $322 f$.

43 Supra n. 41.

44 R. Fiori, “The vir bonus in Cicero's de officiis: Greek philosophy and Roman legal science." Aequum ius, 2014, 187-202 at $197 \mathrm{ff}$.

45 D.H. van Zyl, Justice and equity in Cicero, 49 f where he cites R.G. Tanner, "Cicero on Conscience and Morality," in J. Martyn (ed) Cicero and Virgil: Studies in honour of Harold Hunt, Amsterdam, 1972, 87-112; Also Van Zyl, 97; In the first book of de Officiis Cicero sets out the various duties and gives his son guidelines how to choose between conflicting duties. The subtext is that reason, imparted by nature, gave humankind a sense of right and wrong. Reason helps us to formulate the law of nature. This law is standard against which one can judge the correctness of positive law and one's own behaviour. Harries, 52-58.

46 De Leg. 1,18 and 19; 1, 42; 2, 8; 2, 11 and 2, 14; De Rep 3, 33. 
civil law. ${ }^{47}$ His conscience makes man measure his own behaviour against this law, which is not man-made, but decreed by nature and according to which he may not be judged, but will judge himself. Thus reason and conscience reveal the natural law, which joins men together and imposes morality on them.

If it is accepted that Cicero was not an empty vessel, but made original contributions in many disciplines amongst which Roman law, the question arises which paradigm he represented.

It is generally held that the Roman jurists were practice-orientated..$^{48}$ It is apposite at this point to apply Kuhn's ideas that a paradigm does not only relate to theory, methods, techniques and methodology, but also to assumptions, hypotheses, and values. Kuhn also held that choice of paradigm is to be compared to a choice of religion, while it should also be kept in mind that jurists as a rule are reticent about or even unaware of their philosophical frame of reference on account of their so-called scientific objectivity.

The hypothesis is submitted that Cicero was doubtless a jurist, but that his theoretical and philosophical works on law did not belong to the paradigm

47 De Rep. 3, 33: Est quidem vera lex recta ratio naturae congruens, diffusa in omnes, constans, sempiterna, quae vocet ad officium iubendo, vetando a fraude deterreat; quae tamen neque probos frustra iubet aut vetat nec improbos iubendo aut vetando movet. Huic legi nec obrogari fas est neque derogari ex hac aliquid licet neque tota abrogari potest, nec vero aut per senatum aut per populum solvi hac lege possumus, neque est quaerendus explanator aut interpres eius alius, nec erit alia lex Romae, alia Athenis, alia nunc, alia posthac, sed et omnes gentes et omnes gentes et omni tempore una lex et sempiterna et immutabilis continebit, unusque erit communis quasi magister et imperator omnium deus, ille legis huius inventor, disceptator, lator, cui qui non parebit, ipse se fugiet, ac, naturam hominis aspernatus, hoc ipso luet maximas poenas, etiam si cetera supplicia, quae putantur, effugerit.

48 P. Stein, "Interpretation and legal reasoning in Roman law," Chicago-Kent Law Review , 1994/5 (70), 1539-1556 at 1539; Thomas Finkenauer, "Iustitia und Iustus bei den römischen Juristen," in Rena van den Bergh et. al. (eds.) Meditationes de iure et historia Essays in honour of Laurens Winkel, Fundamina (ed. Specialis) 2014 (20, 1), 288. 
of the traditional Roman jurist. In order to ascertain Cicero's beliefs his discussion of bona fides and the exceptio doli will be analysed and compared to the references thereto in the Corpus Iuris Civilis.

\section{VI. (R)evolutions within Roman law.}

One of the momentous developments within Roman law was the introduction of the bonae fidei contracts, followed by the concomitant exceptio doli during the late republican period.

As starting point the communis opinio on this topic as represented by Kaser has to be briefly covered.

In Das römische Privatrecht ${ }^{49}$ Kaser names the transformation of the formal, limited, strict law of contract into a system adapted to a developed international economy by way of the power of fides the most formidable achievement of the Roman jurists. He is also of the opinion that fides was not restricted to the enforceability of certain agreements, but also determined their content. ${ }^{\circ}$ Whether fides obligations developed as a result of commercial transactions with peregrini or within Roman society is not clear, but that the first recognition of enforceabilty came from the praetor is stated unequivocally, as well as, that in early classical law oportere ex fide bona had become an obligation of the ius civile. ${ }^{5}$

49 M. Kaser, Das römische Privatrecht, I Das altrömische, das vorklassische und klassische Recht, München 1971.

$5^{\circ}$ At 475, 485ff, 509f.

${ }^{11}$ Ibid. Of course, this depends on the definition of ius civile. It should be kept in mind that the definition of ius gentium -often mentioned in this context- is also variable. 
It should come as no surprise that the first mention of bona fides is found in an "extra-legal" source, namely by Cicero. ${ }^{2}$

In Digesta 1.1.10.1 Ulpianus descibes the precepts of law as "to live honestly, not to harm another and to give to everyone his/her due."53

Tony Honoré54 was of the opinion that Ulpianus spent the years between 213 and 218 making a compilation of Roman law for the new citizens of the empire, in other words all inhabitants who had received Roman citizenship in $212 \mathrm{AD}$ and lived, in theory, under Roman law. .5 In consequence a systematic exposé was required with an introduction explaining to these new citizens that Roman law was not limited to Romans, but was a jurisdiction which was reasonable, useful, full of wisdom as well as being practical and well-suited for general application. This was the reason for Ulpianus to look for a concise explanation of the underlying values of Roman law, reflecting the moral philosophy of jurists as well as the Roman people. He found these values in the obvious work of Cicero, namely his De Officiis. ${ }^{6}$

In this work Cicero mentions various mechanisms by which Roman law endeavours to achieve these lofty objectives, of which the most important was bona fides. This was integrated in the formula of the most important legal

${ }^{2}$ De Officiis, III.61,65,67,70.

53 D. 1.1.10.1 (Ulpianus libro primo regularum) Iuris praecepta sunt haec: honeste vivere, alterum non laedere, suum cuique tribuere. Also D. 1.1.10 pr. Iustitia est constans et perpetua voluntas ius suum cuique tribuere. Finkenauer, 288f.; Philip J. Thomas, "The eternal values of Roman law", in J.Sondel, J Reszczyński. P.Ściślicki (eds.) Roman law as Formative of Modern Legal Systems Studies in honour of Wieslaw Litewski, II, Kraków 2003, $174 \mathrm{ff}$.

54 T. Honoré, Ulpian, Oxford 1982.

55 Honoré, 26-33.

${ }^{56}$ This treatise was an important work setting out Roman philosophy. Cicero achieved a synthesis of Stoicism, which forms the basis, with Roman traditions and his own political philosophy. In Chapter 3 Cicero discusses the relationship between law and morality and cites the words found in D.1.1.10. Thus, it is quite probable that Ulpianus found his source there. 
relationships such as guardianship, fiducia and the commercial contracts of sale, lease, labour, work, mandate and partnership. 57

He illustrates his discussion on the position of Roman law between moral rectitude and self-interest with the following examples..$^{8}$

The merchant who is the first to arrive with a ship full of grain during a famine; the house with snakes under the floorboards or constructed with defective building materials. He relates the case of Tiberius Claudis Centumalus, who was instructed by the augurs to demolish parts of a building he owned because it obstructed the flights of birds. Instead he sold the building. When the buyer had to pull down those parts he discovered that this was the reason Claudius had sold and instituted an action on the basis of ex fide bona. Marcus Cato ${ }^{59}$ was the judge and ruled that Claudius had to pay damages, thus laying down the rule that freedom of contract may be restricted by justice which is served by good faith to achieve her goals. Cicero pronounced that bona fides has such force that dishonesty could be banned from Roman law. ${ }^{60}$ To make this point Cicero tells the misfortune of Caius Canius, a Roman who went on holiday in Syracuse and wished to buy gardens.

57 De Officiis, III,70: Q. quidem Scaevola, pontifex maximus, summam vim esse dicebat in omnibus iis arbitriis, in quibus adderetur EX FIDE BONA, fideique bonae nomen existimabat manare latissime, idque versari in tutelis, societatibus, fiduciis, mandatis, rebus emptis, venditis, conductis, locatis, quibus vitae societas contineretur; in iis magni esse iudicis statuere, praesertim cum in plerisque essent iudicia contraria, quid quemque cuique praestare oporteret. https://www.thelatinlibrary.com/cicero/off3.shtml\#79.

${ }^{58}$ De Officiis, III,.50-70. Philip J. Thomas, “The Roman law tradition,” in Petr Bĕlovský, Michal Skřejpek (eds.), The Roman law tradition in societies in transition, Praha 2003, 89-91.

59 The father of Cato minor.

6o De Officiis, III. 61. Quod si Aquiliana definitio vera est, ex omni vita simulatio dissimulatioque tollenda est. 
The local banker Pythius fraudulently misled him into buying his gardens. ${ }^{61}$ When Canius discovered the truth from a neighbour, he had no remedy because the fraud took place before Gaius Aquilius ${ }^{62}$ had introduced the exceptio doli in his praetorian edict.

\section{Origin of negotia bonae fidei and the timeline of their enforceability}

Michel Humbert opened Pandora's box with his seminal work on the Twelve Tables. ${ }^{63}$ His original interpretation of fifth century B. C. Roman society and the (r)evolution caused by this statute are validated by reinterpretation of various texts. The publication of the proceedings of the Collegio di diritto romano, organizzato dal Centro si studi e richerche sui Diritti Antichi (CEDANT) in 2005 combined the latest research on this period in Le Dodici Tavole. ${ }^{64}$ It replaced the traditional myth that Rome during this time still consisted of a small group of primitive subsistence farmers and their class struggle. ${ }^{65}$ The contributions of Dieter Nörr ${ }^{66}$ and David Kremer ${ }^{67}$ who

\footnotetext{
${ }^{61}$ He invited Canius to supper and organised the local fishermen to come and fish in front of the gardens and bring fish to him. He pretends that all fish in Syracuse is in front of his gardens and that the fresh water originates in his gardens.

62 Triggiano, Index, 2010 (18), 373-400.

63https://www.idref.fr/o26928337.

${ }^{64}$ M. Humbert (a cura di), Le Dodici Tavole Dai Decemviri agli Umanisti, Pavia 2005.

65 Theodor Mommsen, Römische Geschichte, vol. II, Berlin, 1917, at Gutenberg.org/files/3061/3061-o.txt; F. Schulz, History of Roman legal science, Oxford, 1946; idem, Geschichte der römischen Rechtswissenschaft, Weimar, 1961; Jolowicz, 72-82.

66 D. Nörr, "Osservazioni in tema di teminologia giuridica predecemvirale e di ius mercatorium mediterraneo: il primo trattato cartaginese-romano,” in Humbert M., Le Dodici Tavole, 147189.

67 D. Kremer, “Trattato internazionali e legge delle Dodici,” in Humbert M., Le Dodici Tavole, 191-207.
} 
argue that Rome was already an important maritime trading nation, support this paradigm change.

It should be kept in mind that the office of praetor was instituted in $367 \mathrm{BC}$ and the division of praetor urbanus and peregrinus is held to date from $242 \mathrm{BC}$; the formula procedure dates from before the Lex Aebutia ( $2^{\text {nd }}$ century BC) ${ }^{68}$ Thus, irrespective of whether the re-interpretation of Roman society and her commercial position in the Mediterrenean basis as depicted in Lo Dodici Tavoli is accepted, even in the traditional narrative of small struggling farmers, it is not difficult to envisage that even in the prepraetorian society everyday small transactions would take place outside the limited number of strictly formal juridical acts. In other words, the law of the Twelve Tables would by necessity be supplemented by a parallel commercial system of customs ruling barter, small short term credit, informal pooling of ressources, lending and borrowing, asking favours based on neighbourly and family solidarity, in short the prototypes of the negotia bonae fidei. This would place the origin of these juristic acts in the ius civile as opposed to the theory that they derive from the ius gentium and were taken over and introduced in Roman law via the edict of the praetor peregrinus. ${ }^{69}$

However, in both narratives the enforceability by the state is introduced centuries after the appearance of the informal consensual practices. Therefor the question arises how international trade and everyday life enforced such agreements prior to recognition thereof in the praetorian edict. A modern answer would refer to the relational contract theory of

${ }^{68}$ M. Kaser, Das römische Zivilprozessrecht, München 1966, 107-115.

69 Much depends on the definitions of ius civile and ius gentium. However, both theories have supporters and a definite answer is unlikely, 
MacNeil and Macaulay..$^{70}$ These authors find mutual trust and solidarity to be the basis of contractual relationships ${ }^{71}$ in small closed groups and enforceability by the threat of exclusion. ${ }^{22}$ To project this theory in Roman society before the conquest of Italy and the Mediterrenean world as well as in a closed group of merchants round the Mediterrenean basin is not a novel hypothesis. ${ }^{73}$ Introduction of these transactions in the edict of the praetor was the inevitable result of the increase in numbers of Romans and commercial contacts and the resulting anonimity.

\section{Digesta}

A study of the Digesta titles dealing with contracts based on good faith disappoints in view of the high hopes held by Cicero and the optimistic conclusion of Kaser that good faith also ruled the content of these contracts.

$7^{70}$ L. Hawthorne, "Relational Contract Theory: Is the antagonism directed at discrete exchanges and presentiation justified?," in G.Glover (ed.). Essays in honour of AJ Kerr, Durban 2006, 137-157.

${ }^{71}$ Id., 153 .

${ }^{72}$ Hawthorne, 143: Macneil has developed the following rules: ... ; and finally, the sanction for bad behaviour is obviously refusal to contract in the future; Also at 45: Beale has stated that: [F]ormal use of contract remedies to settle disputes was unusual; Also n.52 Macaulay ...: Disputes are frequently settled without reference to the contract or to potential or actual legal sanctions.

${ }^{73} \mathrm{Cf}$. Tiziana Chiusi, “Grave est fidem fallere": Vertrauensschutz im römischen Recht”, in Rena van den Bergh et. al. (eds.) Meditationes de iure et historia Essays in honour of Laurens Winkel, Fundamina (ed. Specialis) 2014 (20, 1), 150-162. 
Földi ${ }^{4}$ acknowledges that the Roman jurists developed bona fides, but continues that they did not explore its content in detail, and followed a spontaneous ("naïve") and monist interpretation.75

As mentioned above the Roman jurists were practice orientated. ${ }^{76}$ Analysis of the references to bona fides in the Digesta shows that the texts can be differentiated into two categories, which are direct consequences of trust.

The first deals with persons who were both under and acted on a false belief, in other words the result of misplaced trust. This includes the person who in good faith served as a slave, persons having or acquiring or transferring possession in good faith, and contracting parties acting in good faith.

Secondly, there are texts which mention that the action from the contract was ex fide bona. This was meant to indicate that the enforceability derived from good faith, or trust. As set out supra these transactions were practised for centuries before inclusion in the praetorian edict(s) and formed part of customary ius civile and/or ius gentium. It is submitted that these obligations were originally enforced extrajudically by peer pressure and social exclusion and/or arbitration by old wise men/merchants.

It can, however, be questioned whether the bona fides extended to more than the enforceability on the basis of trust and the discretion granted to the judge in determination of the sentence. The latter consists of a choice

\footnotetext{
74 András Földi, "Traces of the dualist interpretation of good faith in the ius commune until the end of the sixteenth century", in Rena van den Bergh et. al. (eds.) Meditationes de iure et historia Essays in honour of Laurens Winkel, Fundamina (ed. Specialis) 2014 (20, 1), 312-321. 75 At 313 .

${ }^{76}$ It should be remarked that the traditional vision of the Roman jurists is rather idealised, $c f$. Thomas, ZSS RA 2014 (131), 45f, 55f.
} 
between enforcement or non-enforcement as well as the determination of the amount of the sentence in the first instance.

From Cicero's examples one possible interpretation may be the deduction that before the introduction of the exceptio doli ${ }^{77}$ pre-contractual fraud was not taken into consideration in important cases of sale, $7^{78}$ which may be assumed to have taken place by way of stipulatio(nes).

It is, however, generally held that the exceptio doli was a belated introduction to bring the negotia stricti iuris into line with the negotia bonae fidei. In consequence, it stands to reason that the content of the bona fides would be equivalent to that of dolus.

Triggiano ${ }^{79}$ has discussed Cicero's interpretation of dolus as defined by Aquilius Gallus. She also gives a succinct overview of the different definitions found in the Digesta as well as the variety of opinions on this topic among the maestros of Roman law during the last fifty years. ${ }^{80}$

It appears reasonable to conclude that in respect of pre-contractual negotiations dolus forbade and bona fides required refraining from fraudulent misrepresentation. This is validated by prominent classical jurists

77 For divergent opinions about the date and relation to the actio doli $c f$. Triggiano, Index, 2010 (18), 373-400.

${ }^{78}$ Such as the sale of immovable property albeit in Sicily.

79 Supra n. 33.

${ }^{80}$ 382-391 nn. 61- 104. Cf. also James C. Abbott Jr., Roman deceit. Dolus in Latin literature and Roman society, $\quad$ Atlanta 1997 at academia.edu/8183700/ROMAN DECEIT DOLUS IN LATIN LITERATURE ANDROMAN SOCIETY. 
such as Ulpianus, ${ }^{81}$ Paulus, ${ }^{82}$ Pomponius ${ }^{83}$ and Hermogenianus, ${ }^{84}$ who all state that invicem se circumscribere is allowed in sale and lease, which is euphemistically translated as "to overreach each other or the reciprocal taking of advantage." 85 This makes the duty to inform the co-contractant during precontractual negotiations championed by Cicero questionable. This conclusion is supported by the fact that Kaser admits that liability for latent defects relied on the introduction of the actio quanti minoris and the actio redhibitoria by the aediles rather than on good faith. ${ }^{86}$ Furthermore, the continued reliance on stipulationes to make provision for possible eviction and other eventualities ${ }^{87}$ as supplement to the consensual sale also throws doubt on the real force of good faith in litigation.

${ }^{81}$ D. 4.4.16.4 (Ulpianus libro undecimo ad edictum). Idem Pomponius ait in pretio emptionis et venditionis naturaliter licere contrahentibus se circumvenire.

82 D.19.2.22.3 (Paulus libro trigesimo quarto ad edictum). Quemadmodum in emendo et vendendo naturaliter concessum est quod pluris sit minoris emere, quod minoris sit pluris vendere et ita invicem se circumscribere, ia in locationibus quoque et conductionibus iuris est. 83 Supra n. 81.

84 D. 19.2.23 (Hermogenianus libro secondo iuris epitomarum). Et ideo praetextu minoris pensionis, locatione facta, si nullus dolus adversarii probari possit, rescindi locatio non potest.

85 Watson translation of above texts. R. Zimmermann, The law of obligations. Roman foundations of the civilian tradition, Cape Town 1990, 256ff; in the latter's footnotes the authoritative literature can be found.

${ }^{86}$ Kaser, 476.

87 Ibid. 
Finally, the advocated use of the exceptio doli in a procedure issuing from a consensual sale ${ }^{88}$ as well as lease ${ }^{89}$ is another paradox in this context. It can be argued that these texts were the precursor of the exceptio non adimpletu contractus, which was developed during the second life of Roman law. However, the development and endurance of this remedy has been hard to explain in view of the widely stated belief that all contracts became based on good faith during the reception of Roman law.

These contradictions show the hard reality of legal practice, where the stipulatio remained the most common contract, in spite of or just because of the black letter law character of this contract. Cicero's words have found realisation in the $\mathrm{BGB}^{90}$ and other continental codes, ${ }^{91}$ but have remained

\footnotetext{
88 D. 19.1.5.1 (Idem (=Paulus libro tertio ad Sabinum). Sed si falso existimans se damnatum vendere vendiderit, dicendum est agi cum eo ex empto non posse, quoniam doli mali exceptione actor summoveri potest, .... ; D. 19.1.13.9 (Ulpianus libro trigesimo ad edictum). Unde quaeritur, si pars sit pretii soluta et res tradita postea evicta sit, utrum eius rei consequetur pretium integrum ex empto agens an vero quod numeravit? Et puto magis quod numeravit propter doli exceptionem; D. 19.1.42 (Paulus libro secondo questionum). Sed an exception doli mali venditori profutura sit, potest dubitari, ... .

89 D. 19.2.61 pr. (Scaevola libro septimo digestorum). Colonus cum lege locationis non esset comprehensum, ut vineas poneret, nihilo minus in fundo vineas instituit et propter earum fructum denis amplius aureis ager locari coeperat. Quaesitum est, si dominus istum colinum eiectum pensionum debitarum nominee conveniat, an sumptus utiliter factos in vineis instituendis reputare possit doli mali exceptione. Respondit vel expensas consecuturum vel nihil amplius praestaturum.

${ }^{90}$ Section 242 of the German Civil Code provides that the debtor is bound to perform according to the requirements of good faith, ordinary usage being taken into consideration. Section 157 provides that contracts shall be interpreted according to the requirements of good faith. It is accepted that sec 242 supplements the law and determines contractual relationships.

${ }^{91}$ See art 1104 and 1112 of the French Civil Code; art 242 of the German Civil Code; art 2 of the Swiss Civil Code; arts 1175 and 1375 of the Italian Civil Code; art 288 of the Greek Civil Code; art 762-2 of the Portuguese Civil Code; and arts 6:2 and 6:248 of the Dutch Civil Code. Good faith is also recognised in a European context in art 1.7 of the Unidroit Principles and art 1.201 of the Principles of European Contract Law.
} 
echo's in the corridors of academia in the common law jurisdictions and a hollow phrase in everyday legal practices.

\section{Conclusion}

It is difficult to challenge that Cicero was a jurist and wrote the only known theoretical and philosophical works on Roman law during the republic.

Cicero published his theory of justice at the end of his life, which coincided with the demise of the republic. It is submitted that his forensic practice and his political career had given him clear insight into the manipulations of the law culminating in the hollowing out of the republican institutions. The realisation that the rule of law implies more than adherence to the letter of positive law strenghtened Cicero's philosophical beliefs in natural law and his insistence on the necessity of prevalence of what is morally right over expediency. This belief was succinctly expressed by the aphorism used in De Officiis, namely "summum ius, summa iniuria,"92 which Longchamp de Bérier explains as "This saying amounted to a severe criticism of distortions in interpretation, and the soundness of the criticism demonstrated an exceptional knowledge of legal mechanisms. ... It expresses an objection to the juggling of rules to circumvent the law, to abusing, binding or instrumentalising the law, ...” This message explains the spell Cicero held for centuries over Western thinkers.

92 De Officiis 1 33: Existunt etiam saepe iniuriae calumnia quadam et nimis callida sed malitiosa iuris interpretatione. Ex quo illud "summum ius summa iniuria" factum est iam tritum sermone proverbium; F. Longchamps de Bérier, "The status of a bearer of rights within the European legal tradition: the tradition of Rome and Jerusalem - a case study," Fundamina A Journal of Legal History, 2013 (19, 2), 360; Also Stroux, 13ff. 
However, his beliefs in the victory of morality represented ius constituendum rather than the positive law, as the power he attributed to good faith found limited application in classical Roman law.

\section{Bibliography}

Abbott Jr., James C., Roman deceit. Dolus in Latin literature and Roman society, Atlanta 1997 at academia.edu/8183700/ROMAN DECEIT DOLUS IN LATIN LI TERATURE AND-ROMAN SOCIETY.

Barzun, Jacques, From Dawn to Decadence 500 Years of Western Cultural Life 1500 to the Present, New York City 2000.

Burrow, John, A history of histories, London 2009.

Chiusi, Tiziana, "Grave est fidem fallere": Vertrauensschutz im römischen Recht”, in Rena van den Bergh et. al. (eds.) Meditationes de iure et historia Essays in honour of Laurens Winkel, Fundamina (ed. Specialis) $2014(20,1), 150-162$.

Clayton, E. W., "Cicero (106-43 BC)," IEP (Internet Encyclopedia of Philosophy) http://www.iep.utm.edu/cicero/ (consulted on 28/6/2020).

Colish, M.L., The Stoic Tradition from Antiquity to the Early Middle Ages, Leiden 1985, 65-152.

de Zulueta, Francis, The Institutes of Gaius, Part II Commentary, Oxford 1953.

Finkenauer, Thomas, "Iustitia und Iustus bei den römischen Juristen," in Rena van den Bergh et. al. (eds.) Meditationes de iure et historia Essays in honour of Laurens Winkel, Fundamina (ed. Specialis) 2014 (20, 1), 288. 
Fiori, R.,"The vir bonus in Cicero's de officiis: Greek philosophy and Roman legal science." In Aequum ius, 2014, 187-202.

Földi, András, "Traces of the dualist interpretation of good faith in the ius commune until the end of the sixteenth century", in Rena van den Bergh et. al. (eds.) Meditationes de iure et historia Essays in honour of Laurens Winkel, Fundamina (ed. Specialis) 2014 (20, 1), 312-321.

Hanga, V., Römisches Recht und aktuelles Recht," KLIO, 1979 (61, 1-2), 131143 .

Harries, J., Cicero and the Jurists From citizen's law to the lawful state, London 2006.

Hawthorne, L., "Relational Contract Theory: Is the antagonism directed at discrete exchanges and presentiation justified?," in G.Glover (ed.). Essays in honour of AJ Kerr, Durban 2006, 137-157.

Hirai, Masahito, "Objectivity in the Beginnings of the Positivism: Dispute between Auguste Comte and Émile Littré," Archive for Philosophy and the History of Science 2026 (18), 25- 39.

Hoetink, H.R., Rechtsgeleerde opstellen, Alphen a/d Rijn 1982.

Honoré, T., Ulpian, Oxford 1982.

Humbert, M., Le Dodici Tavole Dai Decemviri agli Umanisti, Pavia 2005.

Jolowicz, H.F., Historical Introduction to the study of Roman law, Cambridge 1952.

Juvenal, $\quad$ Satura $\mathrm{X}, \quad$ at $\quad$ http://www.ancientliterature.com/rome juvenal satire x.html.

Kaser, M., Das römische Privatrecht, I Das altrömische, das vorklassische und klassische Recht, München 1971;

Kaser, M., Das römische Zivilprozessrecht, München 1966.

Kremer, D., "Trattato internazionali e legge delle Dodici," in Humbert M., Le Dodici Tavole, 191-207. 
Kuhn, Thomas S., The Structure of Scientific Revolutions, London 1962.

Longchamps de Bérier, F., "The status of a bearer of rights within the European legal tradition: the tradition of Rome and Jerusalem - a case study," Fundamina A Journal of Legal History, 2013 (19, 2), 352366.

Mommsen, Theodor, Römische Geschichte, vol. II, Berlin, 1917, at Gutenberg.org/files/3061/3061-o.txt.

Mommsen, Theodor,

https://www.nobelprize.org/prizes/literature/1902/mommsen/biog

raphical/; $\quad$ https://www.britannica.com/biography/Theodor-

Mommsen; https://www.livius.org/articles/person/mommsen/.

Nörr, D., "Osservazioni in tema di teminologia giuridica predecemvirale e di ius mercatorium mediterraneo: il primo trattato cartaginese-romano," in Humbert M., Le Dodici Tavole, 147-189.

Powell, J. and Paterson, J., Cicero The Advocate, Oxford 2003.

Nussbaum, M.C., "Duties of Justice, Duties of Material Aid: Cicero's Problematic Legacy", The Journal of Political Philosophy, 2000 (8, 2), 176-206.

Plutarch's Lives. Dryden edition revised \& with an introduction by Arthur Hugh Clough in vol. 2, London 1932, 75-115; https://www.britannica.com/biography/Gaius-Marius.

Plutarchus, "The life of Cicero," Lives, at http://classics.mit.edu/Plutarch/cicero.html.

Poynton, J. C., "Smuts holism and evolution sixty years on," Transactions of the Royal Society of South Africa, 1987 (46 3), 181-189.

Reinhardt, T., Marcus Tullius Cicero Topica, Oxford, 2003.

Reiss, Julian and Jan Sprenger, "Scientific Objectivity", The Stanford Encyclopedia of Philosophy (Winter 2017 Edition), Edward N. 
Zalta (ed.)

https://plato.stanford.edu/archives/win2017/entries/scientificobjectivity.

Romein, Jan, Historische lijnen en patronen, Amsterdam 1976.

Schulz, F., History of Roman legal science, Oxford, 1946.

Schulz, F., Geschichte der römischen Rechtswissenschaft, Weimar, 1961.

Slaughter, M.S., "Cicero and his Critics", The Classical Journal, 1921 (17, 3), 210-131.

Smuts, Jan, Holism and evolution, London 1926.

Stein, P., "Interpretation and legal reasoning in Roman law," Chicago-Kent Law Review, 1994/5 (70), 1539-1556.

Stroux. J., "Summum Ius Summa Iniuria. Ein Kapitel aus der Geschichte der interpretatio iuris" in Festschrift Paul Speiser-Sarasin (1926); reprint in J. Stroux, Römische Rechtswissenschaft und Rhetorik, Potsdam 1949, 9-66.

Thomas, Philip J., "The Roman law tradition," in Petr Bĕlovský, Michal Skřejpek (eds.), The Roman law tradition in societies in transition, Praha 2003, 84-96.

Thomas, Philip J., "The eternal values of Roman law", in J.Sondel, J Reszczyński. P.Ściślicki (eds.) Roman law as Formative of Modern Legal Systems Studies in honour of Wieslaw Litewski, II, Kraków 2003, 174ff.

Thomas, Philip, "The standpoint determines the view: Jacques Barzun's theory of asp, in Paul J. du Plessis, New Frontiers Law and society in the Roman world, Edinburgh 2013.

Thomas, Philip, "Ars aequi et boni, legal argumentation and the correct legal solution”, ZSS RA 2014 (131), 41- 59. 
Thomas, Philip, "A Barzunesque view of Cicero: from giant to dwarf and back" in Paul J. du Plessis (ed.), Cicero's Law. Rethinking Roman Law of the late Republic, Edinburgh 2016, 11-25.

Triggiano, Annalisa, “"Conlega et familiaris meus»: note minime su Cicerone e Aquilio Gallo", Index, 2010 (18), 373-400.

Trollope,

A., The life of Cicero, at https://www.gutenberg.org/files/28676/28676-h/28676-h.htm.

Tuori, K., Ancient Roman lawyers and modern legal ideals Studies on the impacts of contemporary concerns in the interpretation of ancient Roman legal history, Frankfurt am Main 2007.

van Zyl, D.H., Justice and Equity in Cicero, a critical evaluation in contextual perspective, Pretoria, 1991.

Viehweg, Th., Topik und Jurisprudenz. Ein Beitrag zur rechtswissenschaflichen Grundlagenforschung, München 1953.

Wieacker, F., Cicero als Advokat: Vortrag gehalten vor der Berliner Juristischen Gesellschaft am 29. April 1964, Berlin 1965.

Zimmermann, R., The law of obligations. Roman foundations of the civilian tradition, Cape Town 1990.

Natural Law, Natural Rights and the American Constitution at http://www.nlnrac.org. 